\title{
Impact of land-use change on catchment water balance: a case study in the central region of South Africa
}

\author{
Yali E. Woyessa * (10 and Worku A. Welderufael
}

\begin{abstract}
An assessment study on the impact of land use change through afforestation on catchment water balance was carried out in one of the semi-arid quaternary catchments (C52A) of the Modder River Basin located in the central region of South Africa. The study used ArcGIS and the Soil and Water Assessment Tool (SWAT) to create scenarios of forest cover areas and to simulate the water balance of C52A, respectively. Climatic data from 1993 to 2020 were used to simulate the catchment water balance. The climatic data from 2011 to 2020 were generated using SWAT weather generator while the rest was obtained from South Africa Weather Service at three weather stations located within C52A catchment. In the C52A quaternary catchment it was envisaged to increase forest cover by considering afforestation on pastureland that is found on slopes $>8 \%$ and $>3 \%$ which created two forest scenarios. The baseline land use [Land use 2000 (LU2000)] which is taken as the base scenario in this study has about 84\% of the catchment area covered with pasture. The two forest scenarios created were: forest scenario1 (FRSE1), i.e. conversion of pastureland on slope $>8 \%$ to forest, and forest scenario2 (FRSE2), i.e. conversion of pastureland on slope $>3 \%$ to forest. The type of forest considered in these scenarios is an evergreen tree, acronym as FRSE by SWAT land use classification. The conversion increased forest cover by $8.3 \%$ and $30.5 \%$ on FRSE1 and FRSE2, respectively. The result of the water balance of the catchment based on the land use scenarios were compared with the baseline land use scenario (LU2000). The result obtained showed that FRSE1 produced a non-significant change both on the mean monthly surface runoff and water yield compared to LU2000. On the other hand, FRSE2 showed 30\% decrease on the mean monthly surface runoff, but increased the mean monthly lateral flow and base flow by $110 \%$ and $254 \%$, respectively compared to the LU2000. Thus, in the overall water balance, the mean monthly water yield of the catchment increased by $171 \%$ on FRSE2 compared to the LU2000. Although there are considerable number of research reports on the negative effect of forest on catchment water yield, this study showed a significant water yield increase when approximately $30 \%$ of the C52A catchment area, which lay on slopes $>3 \%$ and covered by grass, was converted to evergreen forest land. The result showed that having a forest cover on a suitable slope range can bring about a positive effect on the total water yield of a catchment. Therefore, this finding is important for catchment management stakeholders and policy-makers when devising land use and water resources management strategies in a catchment.
\end{abstract}

Keywords: Afforestation, SWAT, Catchment, Land use, Water balance, Water yield

*Correspondence: ywoyessa@cut.ac.za

Department of Civil Engineering, Central University of Technology, Free State, Private Bag X20539, Bloemfontein 9300, South Africa

\section{Introduction}

A recent shift in paradigm regarding land use change elucidates that land use change emerges as a result of interaction between the environment, the biophysical factors and the socio-economic drivers in an environment (Woyessa et al. 2008). The interactions are considered so 
complex and differ from place to place. The interactions are also being taken as the main drivers for an emergent land use change which may affect the sustainable water resource of an environment or ecosystem.

In a catchment, the natural resource in general and the water resource in particular can be affected by change in biophysical factors such as climate, land use/vegetation as well as socio-economic factors such as population, income, etc. In most cases, the change in land use cover can happen due to the decision made by farmers/ farm managers (Couclelis 1986) which is the result of the reflection of the interactions between actors and socioeconomic factors within the environment.

As bare land increases surface runoff, most scholars reported that afforestation decreases stream flow of a catchment). For instance, Guzha et al (2018) reported that increasing forest cover could result in a reduction of annual flow by up to $15 \%$ and annual surface runoff by up to $30 \%$. Many researchers also reported that forest cover can intercept significant amount of a rainfall (e.g., Huber and Irouné 2001), which enhances high evaporation loss from the forest canopy leading to a corresponding reduction of the magnitude of peak flow during floods as well as peak flows during summer season.

Studies elsewhere, however, reported contradictory results on the effect of afforestation on the different components of catchment stream flow. For instance, Pizarro et al. (2006) studied runoff coefficients and their relation to vegetation cover and water yield in Purapel River basin, as influenced by land use for four decades since 1960s. The study concluded that there were no differences in runoff coefficients with the change of vegetation cover but rather due to increased amount of rainfall.

Liu (2004) studied the effect of forest cover in relation to total runoff, surface runoff, and base flow from 13 different watersheds whose area varied from 4.37 to 25,167 $\mathrm{km}^{2}$ with different forest covers in Submontane catchments of the Loess Plateau. The study found that the total runoff and surface runoff decreased, while groundwater flow increased with the increasing forest cover. A catchment experimental study by Bosch and Hewlett (1982) revealed that Pine and eucalypt forest types caused on average $40 \mathrm{~mm}$ change in water yield per $10 \mathrm{~mm}$ change in cover.

Smith and Scott (1992) studied the effect of afforestation on low flows in various regions of South Africa and found that the dry season flow was lower from forested watersheds than from natural grassland. Bonell and Balek (1993) and Sandström (1995) suggested an increased trend in base flow following afforestation in some semi-arid and humid regions. The impact of Pinus patula afforestation on the water yield was studied in the Andean highlands of Ecuador and the results indicated that afforestation with Pinus patula reduces the water yield by about $50 \%$, or an average of $242 \mathrm{~mm}$ year (Buytaert et al. 2007). Some studies have modelled the relationship between evapotranspiration and rainfall with a view to determine the impact of change in land cover on catchment water balance considering the established fact that forest increases catchment evapotranspiration compared to grassland catchments (Zhang et al. 1999).

Farley et al. (2005) concluded that afforestation reduces both dry and wet season flow. While the absolute flow reduction is largest during the wet season, the dry season experiences a larger proportional reduction, which may have important consequences for downstream water supply. Though inconclusive results were reported elsewhere on the impact of afforestation, several studies in South Africa have indicated that forest plantations established in former natural forests, grasslands, or shrub land areas consume more water than the baseline vegetation, reducing water yield (stream flow) (Albaugh et al. 2013; Dye and Versfeld 2007; Gush 2006; Scott and Lesch 1997; Scott and Smith 1997; Smith and Scott 1992). Some of these studies have looked at ways of improving water use efficiency by forest plantations in order to minimize its negative impact on water resources availability.

This paper analyses the influence of afforestation on stream flow and water balance of a quaternary catchment C52A as simulated and predicted by SWAT hydrological model up to the year 2020. In addition, the applied methodology seeks to answer the question of 'what if' scenarios. For instance, what would be the water balance of the catchment if the percentage of forest cover area changes to different magnitudes while other biophysical circumstances remain the same (climate, precipitation, soil type and land features). The SWAT hydrological model, which was used for this study, is a basin-scale comprehensive hydrological model. It is widely used around the world. It was successfully used to simulate the impact of land use change on basin stream flow/water yield both for gauged and un-gauged catchments in South Africa (Welderufael et al. 2013; Tetsoane 2014).

\section{Materials and methods Study area}

The study was conducted in the Central Region of South Africa, in one of the quaternary catchments (C52A in Fig. 1) in the Modder River Basin. The land use map of South Africa which was produced during the year 2000 shows the dominance of grass land in the catchment C52A, covering about $84 \%$ of the land cover. The study catchment has an area of $927.6 \mathrm{~km}^{2}$ and is dominated by land type Dc17 (90\%) and Valsrivier soil forms. The 


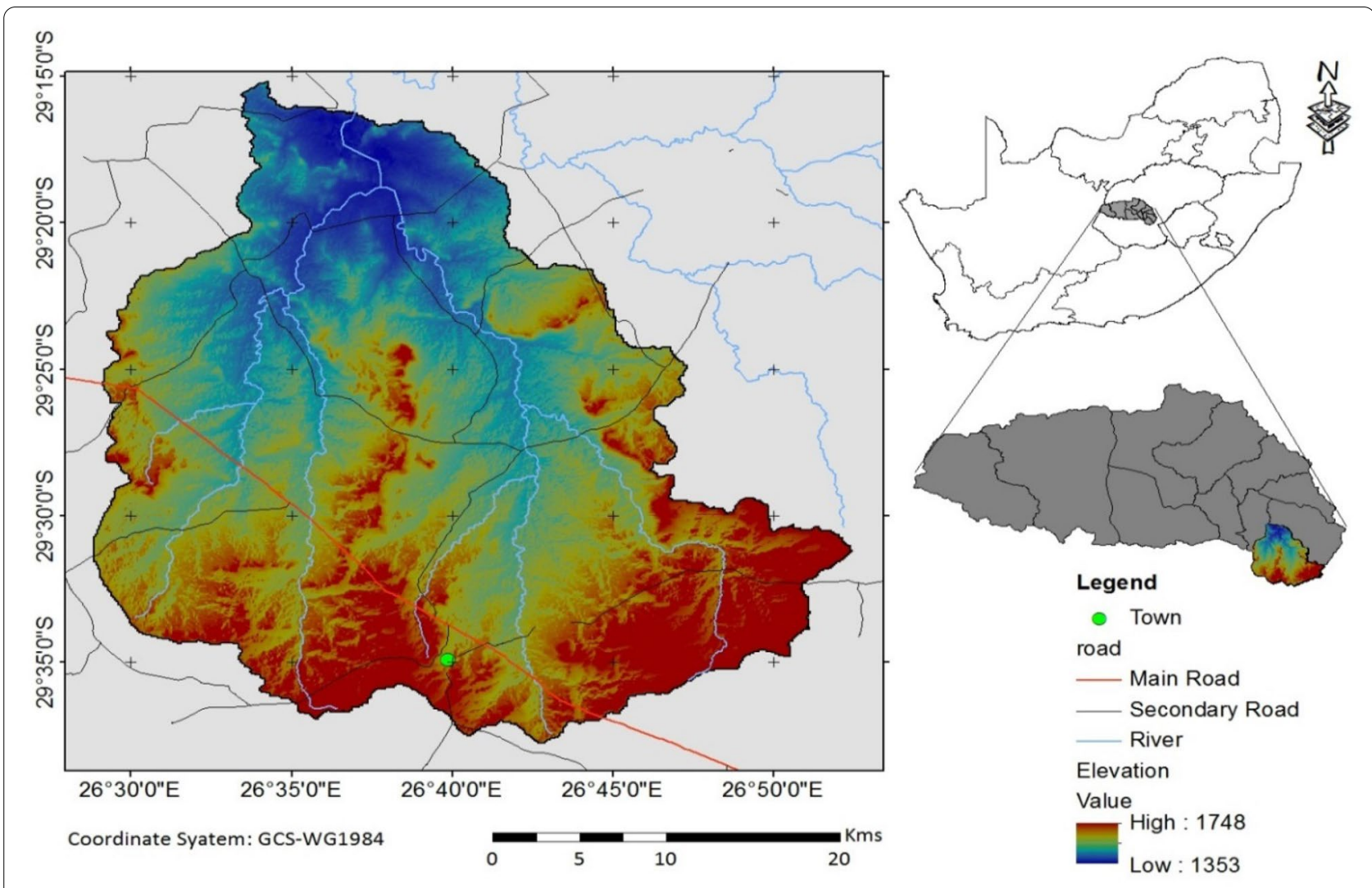

Fig. 1 The study site

annual average rainfall is about $537 \mathrm{~mm}$. The Modder River also originates in this quaternary catchment.

\section{Input data for SWAT}

The SWAT hydrological model requires the following major inputs for setup and running:

- Land use map in shape or raster format.

- Digital elevation model (DEM) in raster format.

- Daily weather data (precipitation, temperature, radiation, humidity, wind speed, etc.).

- Soil map in shape file and soil physico-chemical properties.

- Geographic coordinates of the catchment outlet.

SWAT needs land use input data in shape file format or raster format which should be processed from Landsat images. The processed land use map in shape file data for the year 2000 was obtained from the Institute for Soil, Climate and Water (ISCW) of the Agricultural Research Council (ARC) of South Africa.

The DEM for the Modder River Basin (C52) was obtained from ISCW at a resolution of $90 \mathrm{~m}$ by $90 \mathrm{~m}$.
Rainfall data at three weather stations in the study basin for the period of 1993-2007 were obtained from South African Weather Service (SAWS). Temperature and precipitation data for the same length of period were also obtained from SAWS for three nearby stations. Other climatic data were generated by SWAT through the embedded WXGEN weather generator model (Sharpley and Williams 1990). Statistical parameters used in the weather-generating module were calculated using the 50-year climatic data of C52A catchment (1951-1999) which were obtained from Atlas South Africa. Rainfall from the three stations was spatially distributed to the catchment sub-basins by SWAT. SWAT uses skewed normal distribution method to calculate rainfall amounts in each sub-basin. In addition to the recorded climatic data, additional climatic data up to the year 2020 were simulated by SWAT weather generator in order to simulate the trend of the stream water yield of C52A up to 2020.

Soil map of the catchment (C52A) was obtained from ISCW in shape file format. The soil is covered by land type Dc17 (90\%) and Db89 (8\%). Both land types are dominated by Valsrivier soil forms (Soil Classification Working Group 1991). Therefore, the whole area of C52A 
catchment was considered as Valsrivier series for this study.

For this study, land use map of the year 2000 was used as a benchmark/baseline against which two forest land use scenarios were compared. The first parameterisation was done based on the land use data of 2000. SWAT model uses 27 parameters, all of which but soil parameters were derived internally by the model during the data input, boundary delineation, sub-basin formation and hydrological response unit (HRU) creation processes (Arnold et al. 1998). Three slope classes (0-3\%, $3-8 \%$ and $>8 \%$ ) were considered during superimposing of land use, soil and slope maps to define different HRUs. The three slope-class map generated by SWAT was used as one criterion for creating the different land use/forest scenarios. Sensitivity and calibration analysis for parameters used in the model are carried out using SWAT statistical module and this was done in a previous study for the same quaternary catchment of C52A (Welderufael et al. 2013). Calibration was carried out on the most sensitive input parameters of the model, such as curve number, soil available water capacity, threshold depth of water in the shallow aquifer, etc. There were 13 sensitive parameters in total. In this calibration process, Nash and Sutcliffe efficiency (0.57) together with the coefficient of determination $\left(R^{2}=0.68\right)$, agreement index ( $D$-Index $\left.=0.86\right)$, and residual mean square error $(\mathrm{RMSE}=0.87$ ) were used as measure of efficiency, all of which are found to be satisfactory (Welderufael et al. 2013).

\section{Forest cover scenario creation}

Two forest cover scenarios, from now on referred to as FRSE1 and FRSE2, were created based on the original land use map of C52A for the year 2000. The two forest scenarios were created using ArcGIS 10.1 according to the method used by Welderufael et al. (2011). They were created by considering possible future land use changes. Thus, to create the forest scenarios the following two features were considered:

a. Slope range ( $>3 \%$ and $>8 \%)$.

b. Land use type pasture.

Therefore, land use of 2000 (LU2000) was taken as the base scenario. The two forest scenarios created, based on LU2000, are as follows:

- Forest scenario one (FRSE1) was created by conversion of pastureland on slope $>8 \%$ to forest.

- Forest scenario two (FRSE2) was created by conversion of pastureland on slope $>3 \%$ to forest.
The first scenario (FRSE1) increased the forest covered land area of the catchment from 0.2 to $8.5 \%$ while FRSE2 increased the forest covered land to 39\% (Fig. 2). Table 1 also presents the distribution of the different land uses for each scenario across the three slope ranges $(0-3 \%$, $3-8 \%$ and $>8 \%$ ).

Once the three scenarios were created, SWAT was setup using land use data of 2000 (LU2000) and the inputs such as soil, climate, and DEM data. During the setup process, 12 sub-basins and 34 HRUs were produced by limiting the threshold area of the sub-basin to 3000 hectares. Then after, by keeping all common input data and parameterisation the same, the water balances of the catchment on monthly and yearly basis were simulated for each land use scenario. Comparison and analysis of the scenarios of water balances were conducted using suitable statistical methods.

\section{Results and discussion} Land use change

Table 1 shows that grassland (pasture) is the dominant land use feature on the baseline scenario (LU 2000) in all the three slope ranges, namely $0-3 \%, 3-8 \%$ and $>8 \%$ and comprises $80.2,88.8$ and $91.4 \%$ of the total area of the C52A quaternary catchment, respectively. Under the LU2000 scenario, agricultural landuse is the second highest land cover with total area coverage of $7.8 \%$. Most of the agricultural fields are found on the flatter area of the catchment ( $0-8 \%$ slope). Under the FRSE1 scenario, the land use distribution remains the same as in LU2000 scenario on the two slope ranges, $0-3 \%$ and $3-8 \%$. On slope $>8 \%$, the pastureland under FRSE1 scenario was reduced from $91.4 \%$ to zero and the forest increased from 0.14 to $91.6 \%$. Thus, under FRSE1 scenario the catchment's overall landuse distribution has changed from that of LU2000 in a such way that forest cover land increased from $0.24 \%$ to $7.8 \%$ while pastureland reduced from 84.1 to $75.9 \%$ (Fig. 2 and Table 1). The FRSE2 scenario, has similar landuse distribution with that of LU2000 and FRSE1 scenarios on the slope range of $0-3 \%$ only (Table 1). Under the FRSE2 scenario, pastureland on slopes of $0-3 \%$ and $>8 \%$ was reduced to zero from $88.8 \%$ and $91.4 \%$, respectively, compared to that of LU2000. On the other hand, forest cover area under FRSE2 scenario increased from $0.13 \%$ to $88.9 \%$ and from 0.14 to $91.6 \%$ on the slope ranges of $3-8 \%$ and $>8 \%$, respectively, compared to LU2000. Overall, under FRSE2 scenario, pasture area was reduced from 84.1 to $45.4 \%$ while forest cover increased from 0.24 to $39.0 \%$ when compared to LU 2000 scenario (Fig. 2 and Table 1). 


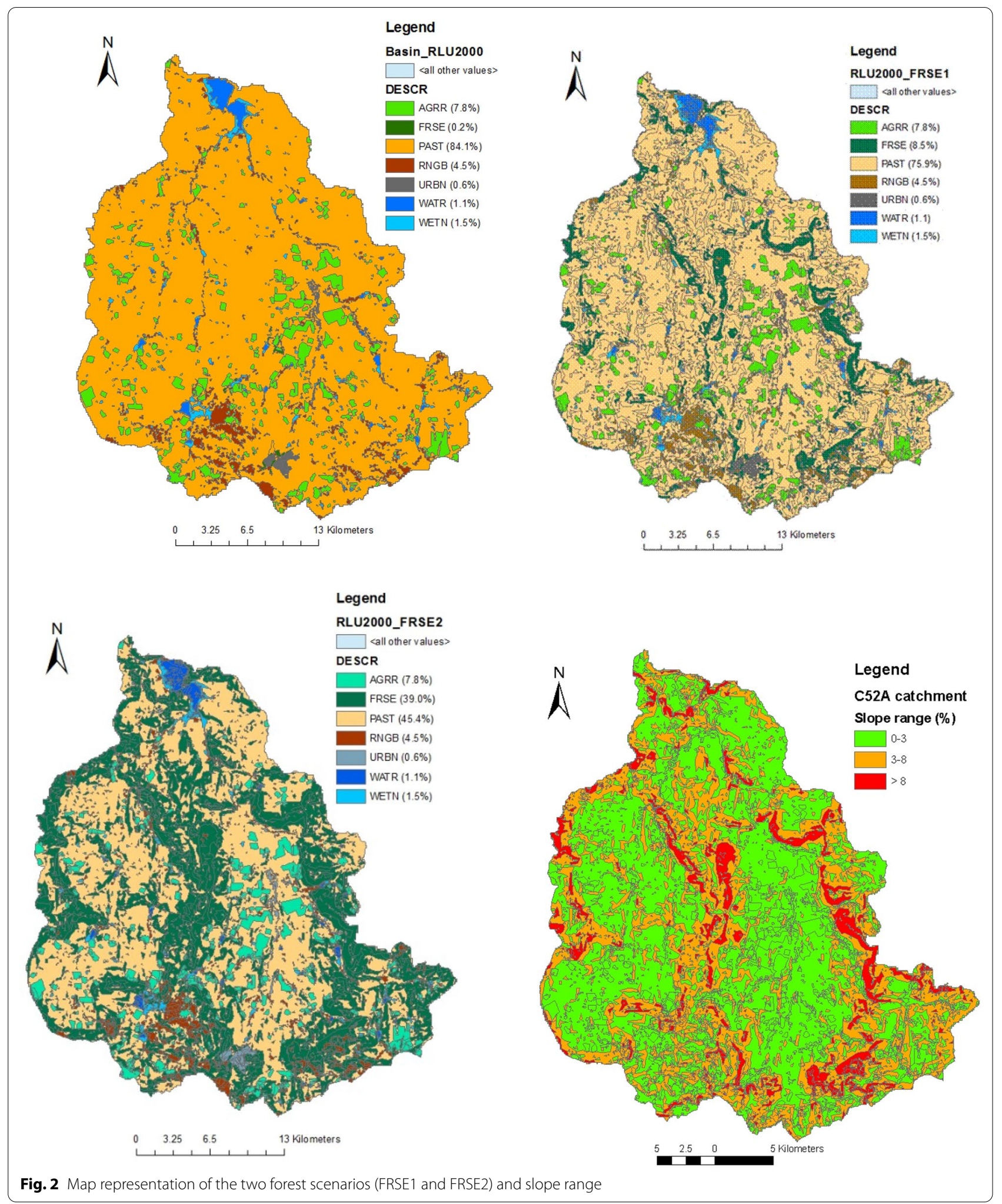


Table 1 Land use distributions of the three scenarios across the slopes

\begin{tabular}{|c|c|c|c|c|c|c|c|}
\hline \multirow[t]{3}{*}{ Slope range (\%) } & \multirow[t]{3}{*}{ Land use } & \multirow{2}{*}{\multicolumn{2}{|c|}{$\frac{\text { Baseline }}{\text { RLU2000 }}$}} & \multirow{2}{*}{\multicolumn{2}{|c|}{$\begin{array}{l}\text { PAST }>8 \% \text { to FRSE } \\
\text { FRSE1 }\end{array}$}} & \multirow{2}{*}{\multicolumn{2}{|c|}{$\begin{array}{l}\text { PAST }>3 \% \text { to FRSE } \\
\text { FRSE2 }\end{array}$}} \\
\hline & & & & & & & \\
\hline & & Area (ha) & $\%$ & Area $\left(m^{2}\right)$ & $\%$ & Area $\left(m^{2}\right)$ & $\%$ \\
\hline \multirow[t]{7}{*}{$0-3$} & Agriculture & 5823.1 & 11.11 & $58,231,422.2$ & 11.11 & $58,231,422.2$ & 11.11 \\
\hline & Forest & 165.8 & 0.32 & $1,657,933.9$ & 0.32 & $1,657,933.9$ & 0.32 \\
\hline & Pasture & $42,008.7$ & 80.16 & $420,087,355.8$ & 80.16 & $420,087,355.8$ & 80.16 \\
\hline & Rangeland & 2295.5 & 4.38 & $22,954,994.6$ & 4.38 & $22,954,994.6$ & 4.38 \\
\hline & Urban & 413.8 & 0.79 & $4,137,642.2$ & 0.79 & $4,137,642.2$ & 0.79 \\
\hline & Water & 697.1 & 1.33 & $6,971,039.5$ & 1.33 & $6,971,039.5$ & 1.33 \\
\hline & Wetland & 1001.8 & 1.91 & $10,018,378.6$ & 1.91 & $10,018,378.6$ & 1.91 \\
\hline Total & & $52,405.8$ & 100.00 & $524,058,766.8$ & 100.00 & $524,058,766.8$ & 100.00 \\
\hline \multirow[t]{7}{*}{$3-8$} & Agriculture & 1358.2 & 4.27 & $13,581,694.3$ & 4.27 & $13,581,694.3$ & 4.27 \\
\hline & Forest & 42.4 & 0.13 & $424,412.5$ & 0.13 & $282,779,720.8$ & 88.91 \\
\hline & Pasture & $28,235.5$ & 88.78 & $282,355,308.3$ & 88.78 & 0.0 & 0.00 \\
\hline & Rangeland & 1358.8 & 4.27 & $13,588,292.2$ & 4.27 & $13,588,292.2$ & 4.27 \\
\hline & Urban & 142.9 & 0.45 & $1,428,801.1$ & 0.45 & $1,428,801.1$ & 0.45 \\
\hline & Water & 340.4 & 1.07 & $3,404,301.5$ & 1.07 & $3,404,301.5$ & 1.07 \\
\hline & Wetland & 326.8 & 1.03 & $3,267,587.0$ & 1.03 & $3,267,587.0$ & 1.03 \\
\hline Total & & $31,805.0$ & 100.00 & $318,050,396.9$ & 100.00 & $318,050,396.9$ & 100.00 \\
\hline \multirow[t]{7}{*}{$>8$} & Agriculture & 46.7 & 0.56 & $467,248.7$ & 0.56 & $467,248.7$ & 0.56 \\
\hline & Forest & 11.8 & 0.14 & $76,423,017.3$ & 91.56 & $76,423,017.3$ & 91.56 \\
\hline & Pasture & 7630.5 & 91.42 & 0.0 & 0.00 & 0.0 & 0.00 \\
\hline & Rangeland & 524.9 & 6.29 & $5,248,974.9$ & 6.29 & $5,248,974.9$ & 6.29 \\
\hline & Urban & 49.2 & 0.59 & $492,500.5$ & 0.59 & $492,500.5$ & 0.59 \\
\hline & Water & 14.7 & 0.18 & $146,910.5$ & 0.18 & $146,910.5$ & 0.18 \\
\hline & Wetland & 68.6 & 0.82 & $685,933.2$ & 0.82 & $685,933.2$ & 0.82 \\
\hline Total & & 8346.4 & 100.00 & $83,464,585.1$ & 100.00 & $83,464,585.1$ & 100.00 \\
\hline \multirow[t]{7}{*}{ Total catchment } & Agriculture & 7228.0 & 7.81 & $72,280,365.2$ & 7.81 & $72,280,365.2$ & 7.81 \\
\hline & Forest & 220.0 & 0.24 & $78,505,363.7$ & 8.48 & $360,860,672.0$ & 38.99 \\
\hline & Pasture & $77,874.7$ & 84.14 & $702,442,664.1$ & 75.89 & $420,087,355.8$ & 45.39 \\
\hline & Rangeland & 4179.2 & 4.51 & $41,792,261.7$ & 4.51 & $41,792,261.7$ & 4.51 \\
\hline & Urban & 605.9 & 0.65 & $6,058,943.8$ & 0.65 & $6,058,943.8$ & 0.65 \\
\hline & Water & 1052.2 & 1.14 & $10,522,251.5$ & 1.14 & $10,522,251.5$ & 1.14 \\
\hline & Wetland & 1397.2 & 1.51 & $13,971,898.8$ & 1.51 & $13,971,898.8$ & 1.51 \\
\hline Catchment Total & & $92,557.2$ & 100.00 & $925,573,748.8$ & 100.00 & $925,573,748.8$ & 100.00 \\
\hline
\end{tabular}

\section{Water balances}

The water balances of the quaternary catchment C52A, based on the baseline scenario (LU2000), and the two forest scenarios (FRSE1 and FRSE2), were simulated using the climatic data recorded up to the year 2007 and simulated by SWAT from 2007 to 2020 . The water yield and the components of the water balance of the two forest scenarios were then compared against each other and with the baseline scenario (LU2000). Figures 3 and 4 show the simulated monthly and annual mean surface water (SURQ) component of the stream flow or the water yield (WYQ) of the C52A at the catchment outlet.
The results showed that FRSE1 produced a non-significant change both on the mean monthly and mean annual surface runoff and water yield compared to LU2000 (Figs. 3, 5, 6, 7). On the other hand, FRSE2 showed $30 \%$ decrease on the mean monthly surface runoff but increased the mean monthly lateral flow and base flow by $110 \%$ and $254 \%$, respectively, compared to the LU2000. Overall, the mean monthly water yield of the catchment has increased by $171 \%$ on FRSE2 compared to the LU2000. Although there are considerable number of research reports indicating the negative effect of forest on catchment total water yield, this study showed a 


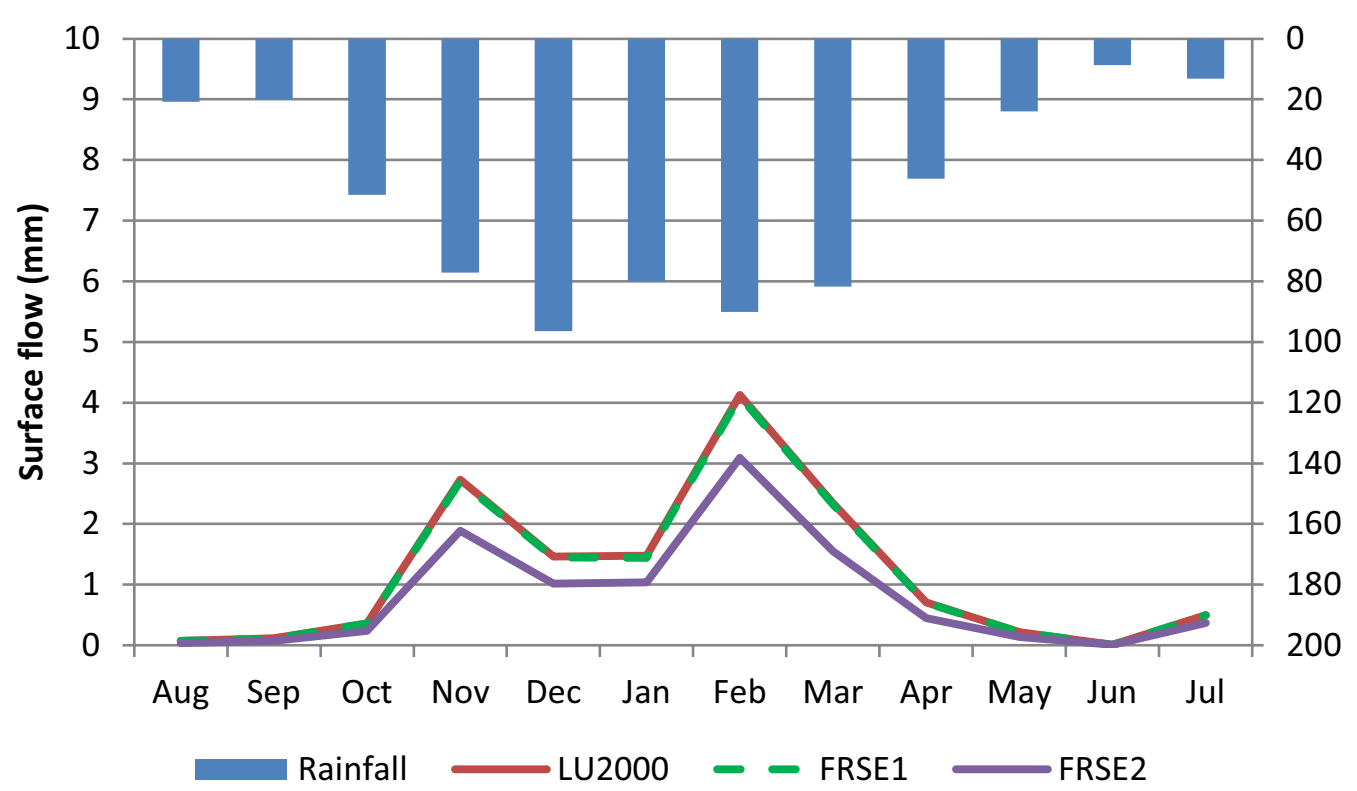

Fig. 3 Monthly surface flow under the two scenarios

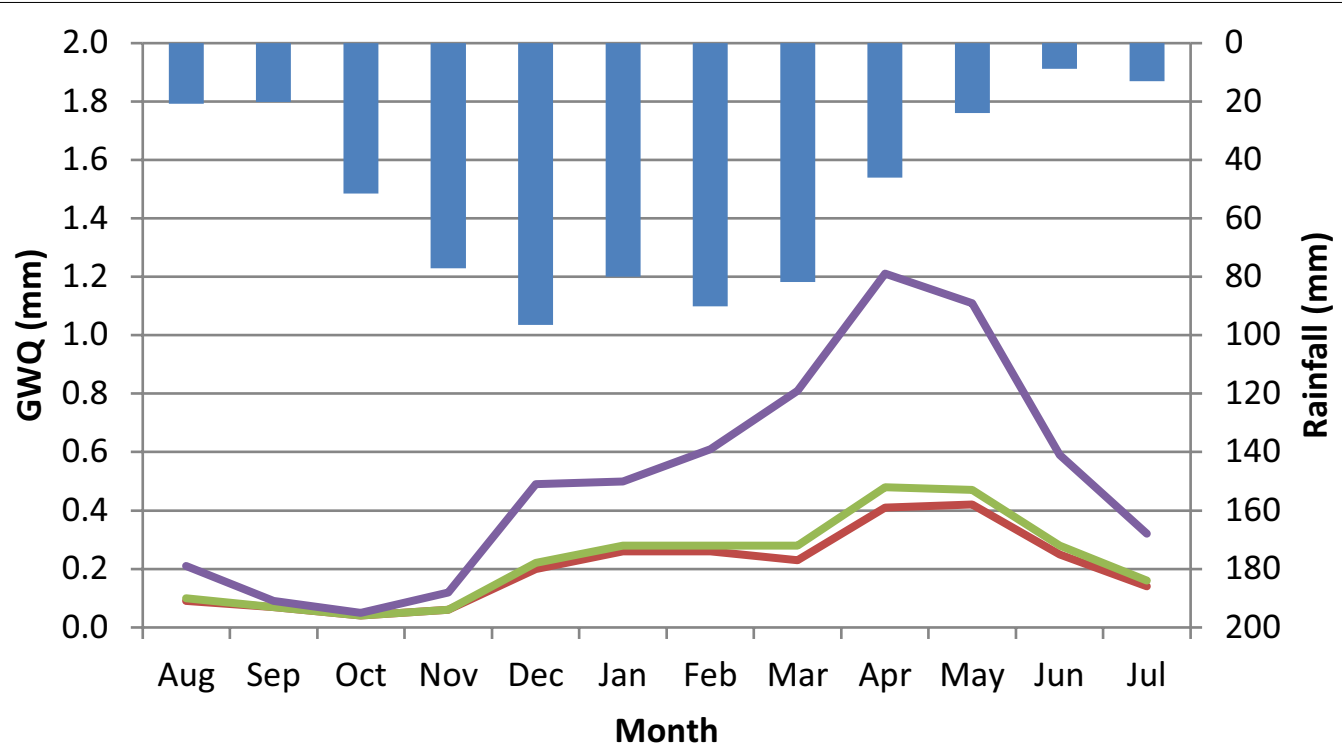

Rainfall

LU2000

FRSE1

FRSE2

Fig. 4 Monthly base flow under the two scenarios

significant water yield increase when approximately $33 \%$ of the C52A catchment area on slopes $>3 \%$ was converted from pastureland to evergreen forest land. This finding shows the dynamic relationship between topographical features of a catchment and the land cover issue and challenges the conventional generalisation which assumes that all forest cover reduces streamflow. This result is also important for catchment management stakeholders and policy-makers when devising land use and water resources management strategies in a catchment. 


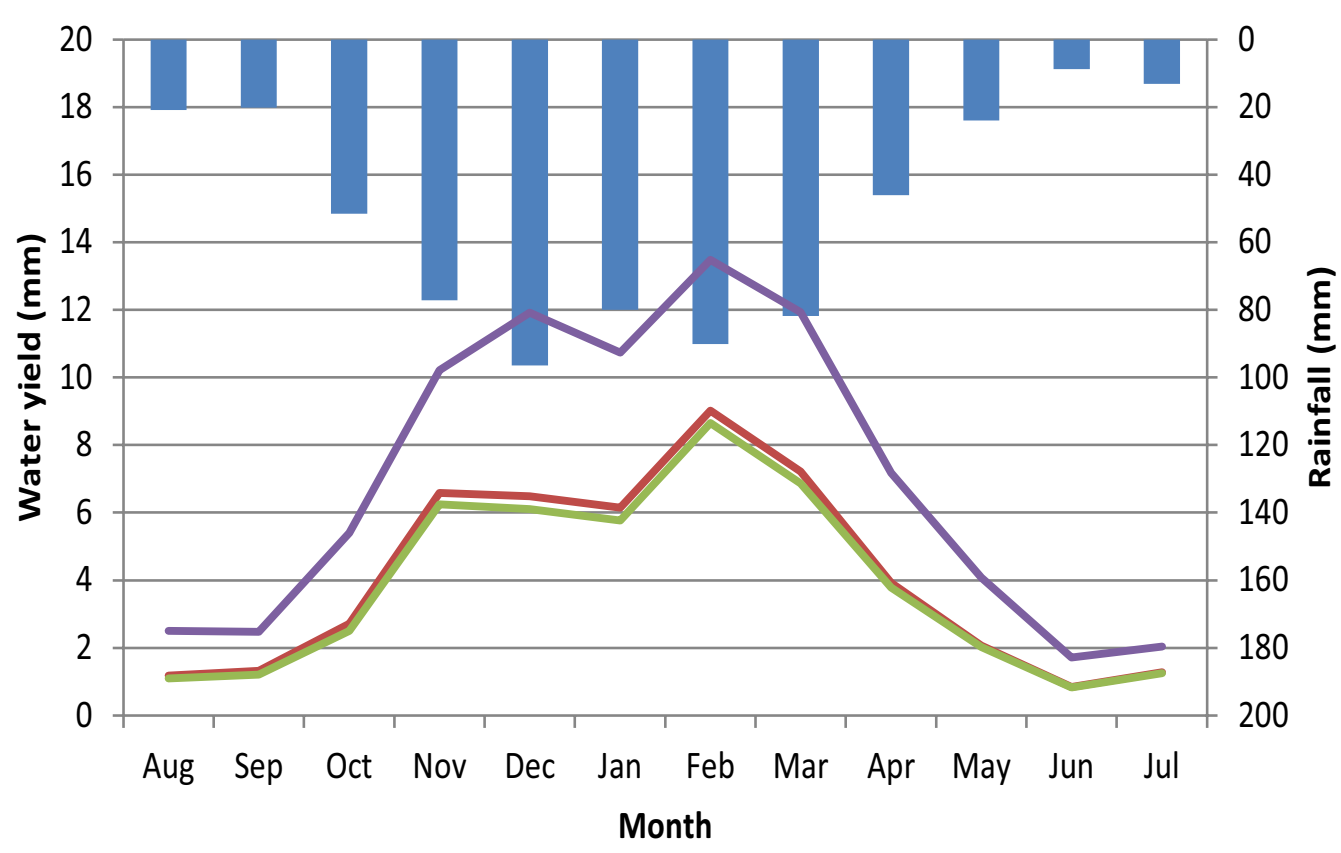

Rainfall —LU2000 FRSE1 -FRSE2

Fig. 5 Monthly water yield under the two scenarios

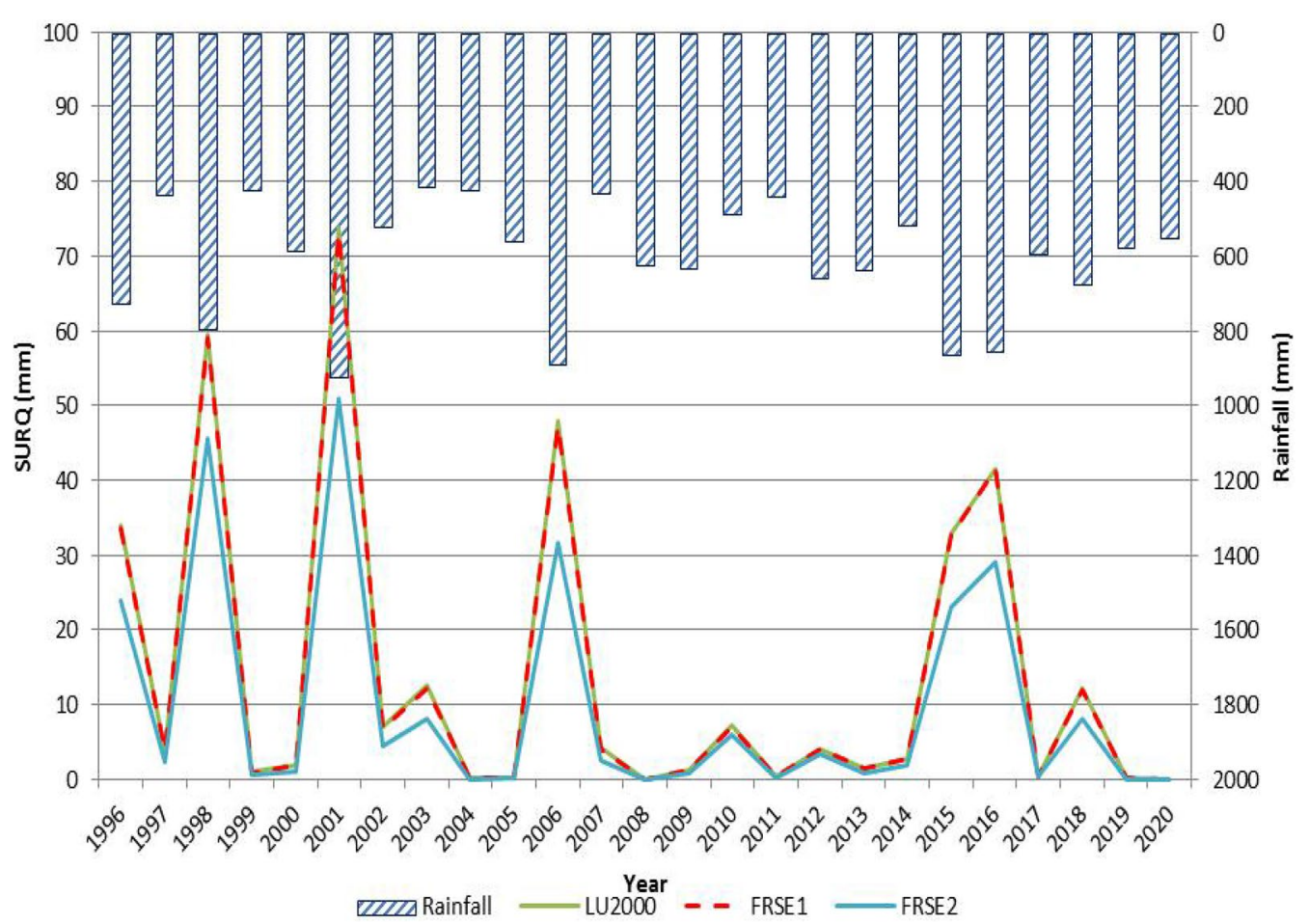

Fig. 6 Annual mean surface water under the two scenarios up to 2020 


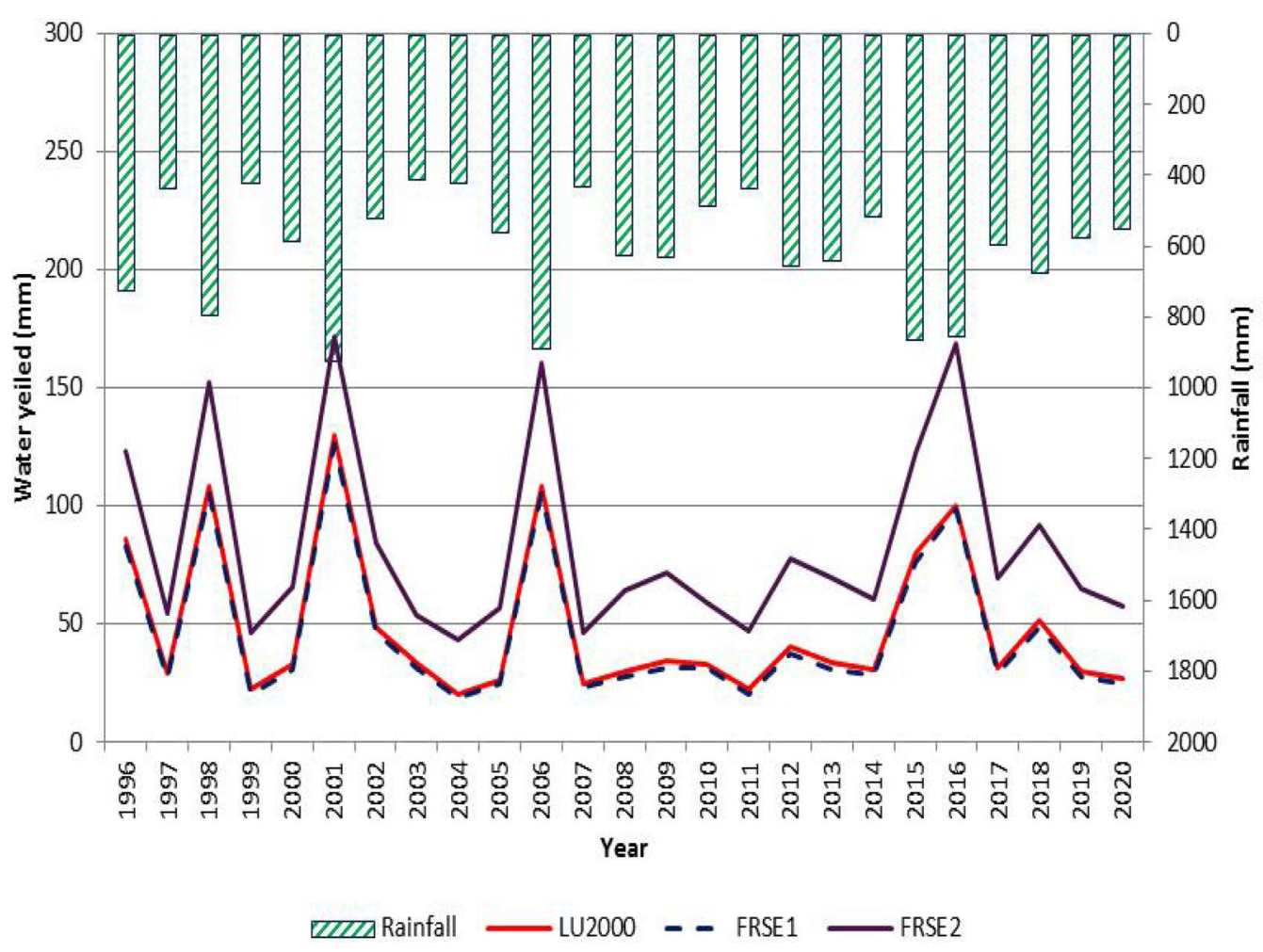

Fig. 7 Annual water yield under the two scenarios up to 2020

\section{Conclusion}

This study focused on evaluating the possible effect of land use change through afforestation on water resources by creating likely scenarios whereby land covered by pasture on a certain slope range are converted to forest in a quaternary catchment located in the semi-arid region of central South Africa. Two scenarios were created, namely Forest scenario one (FRSE1): conversion of pastureland on slope $>8 \%$ to forest; forest scenario two (FRSE2): conversion of pastureland on slope $>3 \%$ to forest. The results showed that FRSE1 produced a non-significant change both on the mean monthly surface runoff and water yield compared to LU2000. On the other hand, FRSE2 showed a $30 \%$ decrease on the mean monthly surface runoff but increased the mean monthly lateral flow and base flow by $110 \%$ and $254 \%$, respectively, compared to the LU2000, indicating positive contribution of forest cover to the total water yield. In spite of reports indicating the negative effect of forest cover on total catchment water yield, this study showed a significant water yield increase when approximately $33 \%$ of the C52A catchment area, which lies on slopes $>3 \%$ and covered by grass, was converted to evergreen forest land. The result showed that a proper combination of forest cover and a suitable slope range can bring about a positive effect on the total water yield of a catchment. This result will contribute positively to the debate and conversation between stakeholders and policy-makers regarding land use and water resources management strategies in the catchment.

\section{Declarations}

\section{Competing interests}

The authors would like to confirm that they have no competing of interest regarding this paper. Both authors worked closely on this project starting from the conception of the project through modelling, analysis, interpretation of the results and write up of the manuscript.

Received: 21 July 2021 Accepted: 11 October 2021

Published online: 25 November 2021

\section{References}

Albaugh JM, Dye PJ, King JS (2013) Eucalyptus and water use in South Africa. Int J For Res 1-11

Arnold JG, Srinivasan R, Muttiah RS, Williams JR (1998) Large area hydrologic modelling and assessment. Part I: model development. J Am Water Resourc Assoc 34(1):73-89.

Bonell M, Balek J (1993) Recent scientific developments and research needs in hydrological processes. In: Bonell M, Hufschmidt M, Gladwell J (eds) Hydrology and water management in the humid tropics. Cambridge University Press, Cambridge 
Bosch JM, Hewlett JD (1982) A review of catchment experiments to determine the effect of vegetation changes on water yield and evapotranspiration. J Hydrol 55(1-4):3-23

Buytaert W, Iñiguez V, De Bièvre B (2007) The effect of afforestation and cultivation on water yield in the Andean páramo. For Ecol Manag. https:// doi.org/10.1016/j.foreco.2007.06.035

Couclelis H (1986) A theoretical framework for alternative models of spatialdecision and behaviour. Ann Assoc Am Geograph 76:95-113

Dye P, Versfeld D (2007) Managing the hydrological impacts of South African plantation forests: an overview. For Ecol Manage 251(1-2):121-128

Farley KA, Jobbagy EG, Jackson RB (2005) Effects of afforestation on water yield: a global synthesis with implications for policy. Global Change Biology 11:1565-1576. https://doi.org/10.1111/j.1365-2486.2005.01011.x

Gush MB (2006) Modeling stream flow reductions resulting from commercial afforestation in South Africa: from research to application, Proceedings of the International Conference on Forest and Water, China

Guzha AC, Rufino MC, Okoth S, Jacobs S, Nóbrega RIB (2018) Impacts of land use and land cover change on surface runoff, discharge and low flows: evidence from East Africa. J Hydrol Reg Stud 15:49-67. https://doi.org/10. 1016/j.ejrh.2017.11.005

Huber A, Iroumé A (2001) Variability of rainfall portioning for different sites and forest covers in Chile. J Hydrol 248:78-92

Liu CM (2004) Study of some problems in water cycle changes of the Yellow River basin. AdvWater Sci 15(5):608-614

Pizarro R, Araya S, Jordan C, Farias C, Flores JP, Bro PB (2006) The effects of changes in vegetative cover on river flows in the Purapel basin of central Chile. J Hydrol 327:249-257

Sandström K (1995) Modeling the effects of rainfall variability on groundwater recharge in semi-arid Tanzania. Nord Hydrol 26:313-330

Scott DF, Lesch W (1997) Stream flow responses to afforestation with Eucalyptus grandis and Pinus patula and to felling in the Mokobulaan experimental catchments, South Africa. J Hydrol 199(3-4):360-377

Scott DF, Smith RE (1997) Preliminary empirical models to predict reductions in annual and low flows resulting from afforestation. Water SA 23:135-140

Smith RE, Scott DF (1992) The effects of afforestation on low flows in various regions of South Africa. Water SA 18(3):185-194

Soil Classification Working Group (1991) Soil classification. A taxonomic system for South Africa. Soil and Irrigation Research Institute, Department of Agriculture Development, Pretoria

Tetsoane M (2014) Evaluation of the swat model in simulating catchment hydrology: case study of the Modder River basin. MTech Dissertation. Unpublished. Central University of Technology, Free State. Bloemfontein

Welderufael WA, Woyessa YE, Edossa DC (2011) Hydrological impact of rainwater harvesting in the Modder River basin of central South Africa. Hydro Earth Syst Sci Discuss 8:1-31. https://doi.org/10.5194/hessd-8-1-2011

Welderufael WA, Woyessa YE, Edossa DC (2013) Impact of rainwater harvesting on water resources of the Modder river basin, central region of South Africa. J Agri Water Manag 116:218-227

Woyessa YE, Welderufael WA, Kinyua JDM (2008) Conceptualisation of the consequence of land use decision on water resources in the central region of South Africa: an agent based modelling perspective. J Transdiscipl Res South Afr 4(1):237-250

Zhang L, Dawes WR, Walker GR (1999) Predicting the effect of vegetation changes on catchment average water balance, CSIRO Technical Report 99/12. CSIRO, Canberra

\section{Publisher's Note}

Springer Nature remains neutral with regard to jurisdictional claims in published maps and institutional affiliations. 